\title{
Studies on Heterotic Trends in Blackgram [Vigna mungo (L.) Hepper] for Yield and Earliness
}

\author{
A. Kavitha Reddy ${ }^{1}$, D. Mohan Reddy², Lakshminarayana R. Vemireddy ${ }^{3}$, \\ P. Sudhakar ${ }^{4}$, B.V. Bhaskara Reddy ${ }^{5}$
}

10.18805/LR-4764

\begin{abstract}
Background: As blackgram cultivation is majorly spread in rain fed areas, breeding short duration and high yielding blackgram varieties is of profound importance to tackle terminal moisture stress and reap impressive yields by breaking the yield plateau. Hence, the present study was aimed to identify highly heterotic cross combinations for yield and earliness.

Methods: Six parents along with $15 \mathrm{~F}_{1} \mathrm{~s}$ were evaluated (rabi, 2019) for seed yield and its component traits along with earliness to estimate the magnitude of heterosis.

Result: The cross LBG-752 $\times$ TBG-104 exhibited heterosis estimates in desirable direction for yield and earliness. The next best crosses were LBG-752 × PU-31, TU-40 × TBG-104, LBG-752 × TU-40 and IPU-2-43 × TBG-104. Because of its autogamous genetic architecture and biological constraints in large scale economic hybrid seed production, heterosis could be exploited only by isolating the early maturing and high yielding segregants followed by bi-parental or recurrent selection in early segregating generations and single plant selection in subsequent generations that would result in short duration and high yielding blackgram variety that fits well into different ecological niches.
\end{abstract}

Key words: Better parent heterosis, Blackgram, Earliness, Mid-parent heterosis, Seed yield, Yield components.

\section{INTRODUCTION}

Blackgram is one of the extensively cultivated grain legumes in arid and semi-arid areas as a catch crop, mulch crop, inter crop, mixed crop and green crop, highlighting the success of this crop as a best fit into multiple and inter cropping systems which forms the basis of sustainable farming system. As 'Protein Calorie Malnutrition (PCM)' is a global concern especially in infants, young children and nursing mothers, in this lane blackgram has a potent future to address all the future food and nutritional challenges of the ever growing population.

In India, blackgram is being cultivated over an area of $5.60 \mathrm{M}$ ha, with a production of $3.06 \mathrm{Mt}$ and productivity of $546 \mathrm{~kg} \mathrm{ha}^{-1}$ (Anonymous, 2018-19). Andhra Pradesh is one of the largest blackgram growing states in India with an area of 3.81 lakh hectares, production of 3.13 lakh tonnes and productivity of $821.5 \mathrm{~kg} \mathrm{ha}^{-1}$ (Anonymous, 2018-19). The pulse requirement in the country is projected at $32 \mathrm{M}$ t by 2030 A.D and $39 \mathrm{M}$ t by 2050 A.D at an annual growth rate of $2.2 \%$ requiring an all-round efforts and strategic steps in research to enhance the production levels (Ahlawat et al. 2016). Globally, more preference towards non-meat protein sources than animal-based foods is observed indicating the need to enhance production level of pulses for a sustainable future. Increasing the cultivable area and crop productivity are the general ways to increase production, among which increasing productivity is more feasible solution. But, the main factor back stacking the yield enhancement of black gram is non-availability of stable and high yielding varieties.

The superiority of $F_{1}$ over the parents is referred to as heterosis or hybrid vigour. Reports of varying degrees of
'Department of Genetics and Plant Breeding, S.V. Agricultural College, Tirupati-517 502, Andhra Pradesh, India.

${ }^{2}$ Department of Genetics and Plant Breeding, IFT, Regional Agricultural Research Station, Tirupati-517 502, Andhra Pradesh, India.

${ }^{3}$ Department of Molecular Biology and Biotechnology, S.V. Agricultural College, Tirupati-517 502, Andhra Pradesh, India.

${ }^{4}$ Department of Crop Physiology, IFT, Regional Agricultural Research Station, Tirupati-517 502, Andhra Pradesh, India.

${ }^{5}$ Department of Plant Pathology, IFT, Regional Agricultural Research Station, Tirupati-517 502, Andhra Pradesh, India.

Corresponding Author: A. Kavitha Reddy, Department of Genetics and Plant Breeding, S.V. Agricultural College, Tirupati-517 502, Andhra Pradesh, India. Email: appgari@gmail.com

How to cite this article: Reddy, A.K., Reddy, D.M., Vemireddy, L.R., Sudhakar, P. and Bhaskara Reddy, B.V. (2021). Studies on Heterotic Trends in Blackgram [Vigna mungo (L.) Hepper] for Yield and Earliness. Legume Research. DOI: 10.18805/LR-4764.

Submitted: 04-08-2021 Accepted: 16-11-2021 Online: 27-12-2021

heterosis in blackgram has generated an interest among the plant breeders for the development of high yielding varieties. In a self-pollinated crop like blackgram, the possibility of commercial exploitation of heterosis is rather remote, particularly because of its floral biology and lack of economic hybrid seed production strategies. Therefore, highly heterotic crosses can be employed in developing high yielding pure line varieties through recurrent selection in segregating generations. Moreover, the knowledge of heterosis would help in elimination of poor crosses in early 
generations of testing and identification of superior segregants. Hence, the present study was carried out to estimate the nature and magnitude of heterosis with respect to earliness, yield and yield component traits in 15 blackgram crosses developed by half diallel mating among six diverse parents.

\section{MATERIALS AND METHODS}

The experimental material for this study consisted of six diverse blackgram genotypes viz., LBG-752, TU-40, PU-31, IPU-2-43, TBG-104, GBG-1 and $15 \mathrm{~F}_{1} \mathrm{~s}$ derived by half diallel mating among the parents (kharif, 2018). The salient features of parents is presented in Table 1.

The six parents and $15 \mathrm{~F}_{1}$ s were sown in randomized block design with two replications during rabi, 2019 (Fig1). Each entry was sown in 2 rows by dibbling the seeds in $3 \mathrm{~m}$ length, with a spacing of $30 \mathrm{~cm}$ between the rows and 10 $\mathrm{cm}$ within the row. Common crop management practices like plant protection, weeding and irrigation were carried out to maintain good crop growth. The observations were recorded on five randomly tagged competitive plants from the centre of row in each genotype in each replication for all the yield and yield component traits (plant height, number of primary branches per plant, number of clusters per plant, number of pods per plant, pod length, number of seeds per pod, seed yield per plant, 100 seed weight and harvest index) except days to $50 \%$ flowering and days to maturity which were recorded on per plot basis.

The mean of these five plants were used to compute relative heterosis $(\mathrm{MH})$, heterobeltiosis $(\mathrm{BH})$. Percentage of mid parent heterosis $(\mathrm{MH})$ and better parent heterosis $(\mathrm{BH})$ for twelve traits were presented in the Tables 2, 3, 4 and 5, respectively.

The superiority of $F_{1}$ over the mid-parent and better parent was estimated as per the formula given by Shull (1908) and Fonesca and Patterson (1968), respectively. The significance of heterosis was tested by using 't' test as suggested by Snedecor and Cochran (1967) and Paschal and Wilcox (1975).

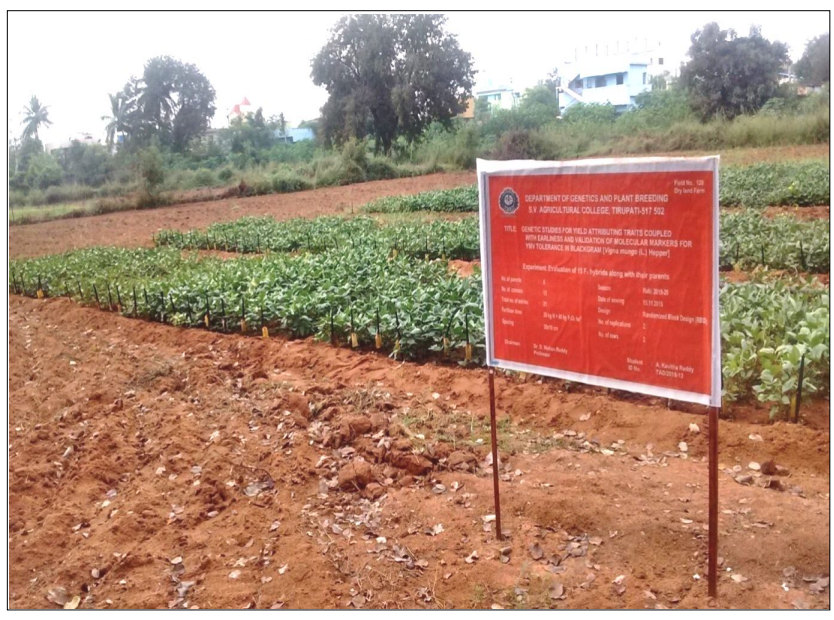

Fig 1: Field view of $F_{1}$ evaluation block (rabi, 2019).

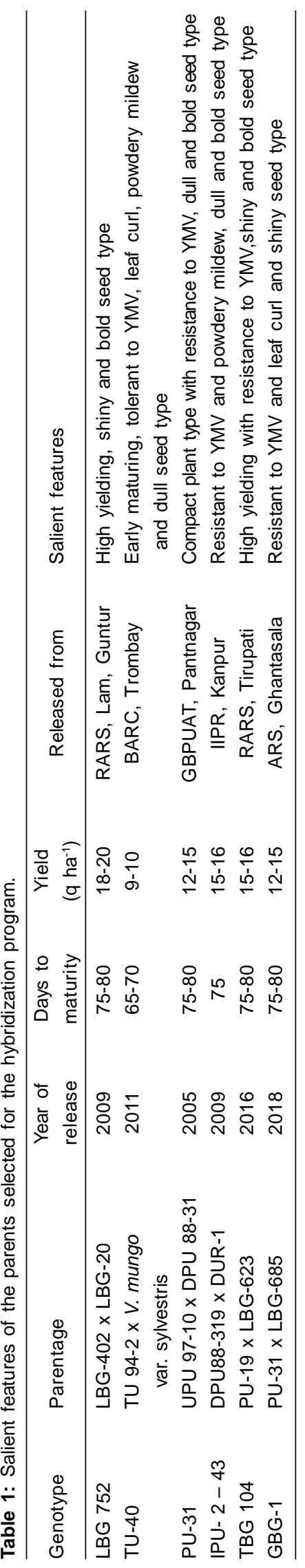

2 


\section{RESULTS AND DISCUSSION}

For days to 50 per cent flowering and days to maturity, negative estimates of heterosis are desirable to the plant breeder mainly to infuse earliness in the genotypes. The range of mid parental heterosis for days to $50 \%$ flowering varied between $-9.09 \%$ (LBG-752 × GBG-1) and $-1.35 \%$ (PU$31 \times$ TBG-104). Maximum and minimum values for better parent heterosis were displayed by TU-40 × TBG-104 (7.14\%) and LBG-752 × TBG-104, PU-31 × TBG-104 (2.82 $\%)$, respectively. The crosses LBG-752 $\times$ GBG-1, TU-40 $\times$ TBG-104, LBG-752 × IPU-2-43, PU-31 × IPU-2-43 and LBG$752 \times$ PU-31 could yield early flowering segregants in further generations. Significant negative heterosis for days to 50 per cent flowering was previously reported by Kant and

Table 2: Percentage of mid parent heterosis $(\mathrm{MH})$ and better parent heterosis $(\mathrm{BH})$ for days to $50 \%$ flowering, days to maturity and plant height $(\mathrm{cm})$.

\begin{tabular}{|c|c|c|c|c|c|c|}
\hline \multirow{2}{*}{ Crosses } & \multicolumn{2}{|c|}{ Days to $50 \%$ flowering } & \multicolumn{2}{|c|}{ Days to maturity } & \multicolumn{2}{|c|}{ Plant height $(\mathrm{cm})$} \\
\hline & $\mathrm{MH}$ & $\mathrm{BH}$ & $\mathrm{MH}$ & $\mathrm{BH}$ & $\mathrm{MH}$ & $\mathrm{BH}$ \\
\hline LBG-752 × TU-40 & -4.70 & 1.43 & 3.47 & $10.37^{* *}$ & 11.02 & 2.33 \\
\hline LBG-752 × PU-31 & $-6.41^{*}$ & $-5.19^{*}$ & 5.05 & $8.33^{* *}$ & $21.78^{* *}$ & 10.04 \\
\hline LBG-752 × IPU-2-43 & $-7.79^{*}$ & $-5.33^{*}$ & -0.68 & 3.55 & -1.48 & -8.84 \\
\hline LBG-752 × TBG-104 & -2.67 & 2.82 & $-6.31 *$ & $-4.73^{*}$ & $38.84^{* *}$ & $36.03^{* *}$ \\
\hline LBG-752 × GBG-1 & $-9.09^{* *}$ & $-6.67^{*}$ & -3.61 & -3.29 & -2.20 & -6.74 \\
\hline TU-40 × PU-31 & -6.12 & -1.43 & 6.09 * & $9.63^{* *}$ & $62.04^{* *}$ & $58.57^{* *}$ \\
\hline TU-40 $\times$ IPU-2-43 & -6.21 & -2.86 & $6.52 *$ & $8.89^{* *}$ & 7.16 & 6.7 \\
\hline TU-40 × TBG-104 & $-7.80^{*}$ & $-7.14^{*}$ & 1.77 & $6.67^{* *}$ & $35.21^{* *}$ & $22.31^{* *}$ \\
\hline TU-40 × GBG-1 & $-7.59^{*}$ & -4.29 & 0.35 & $6.67^{\star *}$ & -3.41 & $-14.75^{\star}$ \\
\hline PU-31 × IPU-2-43 & $-6.58^{*}$ & $-5.33^{*}$ & 3.16 & 4.26 & 14.05 & 11.14 \\
\hline PU-31 × TBG-104 & -1.35 & 2.82 & -0.68 & 0.69 & 9.53 & -2.81 \\
\hline PU-31 × GBG-1 & -5.26 & -4.00 & -1.35 & 1.39 & $18.53^{*}$ & 2.66 \\
\hline IPU-2-43 × TBG-104 & $-6.85^{*}$ & -4.23 & 5.88 * & $8.51^{* *}$ & 11.78 & 1.50 \\
\hline IPU-2-43 × GBG-1 & $-6.67^{*}$ & $-6.67^{*}$ & 0.34 & 4.26 & 2.82 & -8.93 \\
\hline TBG-104 × GBG-1 & -2.74 & $-5.33^{*}$ & 0.67 & 2.03 & -5.92 & -8.49 \\
\hline S.E. & 0.76 & 0.88 & 1.36 & 1.57 & 1.57 & 1.81 \\
\hline
\end{tabular}

${ }^{*}$ Significant at $5 \%$ level; ${ }^{*}$ Significant at $1 \%$ level.

$\mathrm{MH}-$ Mid parent heterosis; $\mathrm{BH}-$ Better parent heterosis.

Table 3: Percentage of mid parent heterosis $(\mathrm{MH})$ and better parent heterosis $(\mathrm{BH})$ for no. of primary branches per plant, no. of clusters per plant and no. of pods per cluster.

\begin{tabular}{|c|c|c|c|c|c|c|}
\hline \multirow{2}{*}{ Crosses } & \multicolumn{2}{|c|}{ No. of primary branches per plant } & \multicolumn{2}{|c|}{ No. of clusters per plant } & \multicolumn{2}{|c|}{ No. of clusters per plant } \\
\hline & $\mathrm{MH}$ & $\mathrm{BH}$ & $\mathrm{MH}$ & $\mathrm{BH}$ & $\mathrm{MH}$ & $\mathrm{BH}$ \\
\hline LBG-752 × TU-40 & 9.86 & 8.33 & $41.30^{* *}$ & $35.42^{*}$ & 3.13 & 3.13 \\
\hline LBG-752 × PU-31 & 9.68 & -2.86 & $53.85^{* *}$ & $35.42^{*}$ & 10.00 & 3.13 \\
\hline LBG-752 $\times$ IPU-2-43 & $-37.84^{* *}$ & $-41.03^{* *}$ & 10.24 & 3.67 & -6.25 & -6.25 \\
\hline LBG-752 × TBG-104 & 10.81 & 5.13 & $70.15^{\star \star}$ & $62.86^{* *}$ & 4.62 & 3.03 \\
\hline LBG-752 × GBG-1 & -12.28 & $-28.57^{\star *}$ & $41.05^{\star *}$ & $39.58^{* *}$ & 1.54 & 0.00 \\
\hline TU-40 $\times$ PU-31 & $-30.16^{* *}$ & $-38.89^{* *}$ & $59.01^{* *}$ & $45.45^{* *}$ & 10.00 & 3.13 \\
\hline TU-40 $\times$ IPU-2-43 & 6.67 & 2.56 & 4.57 & -5.50 & $18.75^{\star *}$ & $18.75^{*}$ \\
\hline TU-40 × TBG-104 & -9.33 & -12.82 & $44.04^{* *}$ & $32.38^{*}$ & -1.54 & -3.03 \\
\hline TU-40 × GBG-1 & -10.34 & $-27.78^{\star *}$ & $37.36^{\star *}$ & $32.98^{*}$ & 7.69 & 6.06 \\
\hline PU-31 × IPU-2-43 & 3.03 & -12.82 & 13.19 & -5.5 & -10.00 & $-15.63^{*}$ \\
\hline PU-31 × TBG-104 & -12.12 & $-25.64^{* *}$ & 12.36 & -4.76 & $24.59^{* *}$ & $15.15^{*}$ \\
\hline PU-31 × GBG-1 & 14.29 & 3.70 & $47.31^{\star *}$ & $30.85^{\star}$ & 11.48 & 3.03 \\
\hline IPU-2-43 × TBG-104 & 7.69 & 7.69 & -0.93 & -2.75 & $16.92^{* *}$ & $15.15^{\star}$ \\
\hline IPU-2-43 × GBG-1 & $24.59^{* *}$ & -2.56 & -5.42 & -11.93 & 4.62 & 3.03 \\
\hline TBG-104 × GBG-1 & $31.15^{* *}$ & 2.56 & 2.51 & -2.86 & 6.06 & 6.06 \\
\hline S.E. & 0.24 & 0.28 & 1.12 & 1.30 & 0.19 & 0.22 \\
\hline
\end{tabular}

${ }^{*}$ Significant at $5 \%$ level; ${ }^{*}$ Significant at $1 \%$ level.

$\mathrm{MH}$ - Mid parent heterosis; BH- Better parent heterosis. 
Srivastava (2012), Thamodharan et al. (2016), Suguna et al. (2017), Shalini and Lal (2019) and Elangaimannan et al. (2018).

The cross LBG-752 $\times$ TBG-104 exhibited both mid and better parent heterosis in the desirable direction for days to maturity. Hence, it would be a promising cross that would yield early maturing segregants which would take us a way forward in developing super early lines of blackgram. Negative estimates of heterosis for days to maturity were also manifested in the reports of Kant and Srivastava (2012), Thamodharan et al. (2016) and Suguna et al. (2017).

The estimates of relative heterosis for seed yield per plant ranged from $-21.41 \%$ (PU-31 x IPU-2-43) to $80.81 \%$ (LBG-752 × TBG-104). The magnitude of heterosis over better parent for seed yield per plant varied between -34.57 $\%(P U-31 \times$ IPU-2-43) and $66.27 \%$ (LBG-752 × TBG-104). Out of 15 crosses, six combinations showed positively significant values over both mid parent and better parent. The cross LBG-752 $\times$ TBG-104 followed by PU-31 $\times$ GBG-1, TU-40 $\times$ PU-31, LBG-752 $\times$ TU-40 and LBG-752 $\times$ PU-31 were regarded as the desirable crosses for seed yield. Positively significant estimates of heterosis for seed yield per plant were also registered by Kalia et al. (1988), Neog and Talukdar (1999), Saravanan et al. (2004), Elangaimannan et al. (2008), Kant and Srivastava (2012), Karande et al. (2013), Bhagirath et al. (2013), Thamodharan et al. (2016), Kumar et al. (2017), Shalini and Lal (2019).

The crosses viz., LBG-752 × TBG-104, TU-40 × TBG104 and TU-40 $\times$ PU-31 showed desirable significant heterosis for plant height. The top five crosses that recorded positively significant values of mid parent and better parent heterosis for number of clusters per plant were LBG-752 $\times$ TBG-104, TU-40 × PU-31, LBG-752 × GBG-1, LBG-752 × PU-31 and LBG-752 $\times$ TU-40. The crosses TU-40 $\times$ IPU-2-43, PU-31 $\times$ TBG-104 and IPU-2-43 × TBG-104 exhibited significant heterosis in desirable directions over both mid and better parents for number of pods per cluster.

In relation to pods per plant, significant and positive heterosis over mid and better parents in desirable direction was manifested by the crosses viz., TU-40 $\times$ PU-31, LBG$752 \times$ TBG-104, LBG-752 × TU-40, LBG-752 × PU-31 and PU-31 $\times$ GBG-1. The cross LBG-752 $\times$ TBG-104 was the only combination that showed positively significant heterosis values over mid parent and better parent for number of seeds per pod. The crosses viz., LBG-752 × TBG-104 and LBG$752 \times$ PU-31 registered significant mid and better parent heterosis values in the desirable direction for harvest index. An insight into the results of heterosis revealed that, LBG$752 \times$ TBG-104 was the best cross that expressed significant mid parent heterosis in desirable direction for seven traits (days to maturity, plant height, number of clusters per plant, number of pods per plant, number of seeds per pod, seed yield per plant and harvest index) and significant better parent heterosis for seven characters (days to maturity, plant height, number of clusters per plant, number of pods per plant, number of seeds per pod, seed yield per plant and harvest index). The next best crosses were LBG-752 $\times$ PU31, TU-40 × TBG-104, LBG-752 × TU-40 and IPU-2-43 $\times$ TBG-104. Hence, these crosses can be utilized for extracting transgressive segregants with high yielding ability coupled with earliness.

Table 4: Percentage of mid parent heterosis $(\mathrm{MH})$ and better parent heterosis $(\mathrm{BH})$ for no. of pods per plant, pod length $(\mathrm{cm})$ and no. of seeds per pod.

\begin{tabular}{|c|c|c|c|c|c|c|}
\hline \multirow{2}{*}{ Crosses } & \multicolumn{2}{|c|}{ No. of pods per plant } & \multicolumn{2}{|c|}{ Pod length (cm) } & \multicolumn{2}{|c|}{ No. of seeds per pod } \\
\hline & $\mathrm{MH}$ & $\mathrm{BH}$ & $\mathrm{MH}$ & $\mathrm{BH}$ & $\mathrm{MH}$ & $\mathrm{BH}$ \\
\hline LBG-752 × TU-40 & $95.93^{* *}$ & $68.48^{* *}$ & $8.07^{*}$ & $-9.87^{*}$ & 6.11 & 5.30 \\
\hline LBG-752 × PU-31 & $74.68^{* *}$ & $58.37^{* *}$ & 6.72 & -0.93 & 7.35 & 4.29 \\
\hline LBG-752 × IPU-2-43 & 18.97 & 12.94 & -5.82 & $-14.15^{* *}$ & $-11.11^{* *}$ & $-13.04^{* *}$ \\
\hline LBG-752 × TBG-104 & $94.16^{* *}$ & $73.85^{\star *}$ & -0.40 & -6.70 & $12.78^{* *}$ & $11.94^{*}$ \\
\hline LBG-752 × GBG-1 & $30.47^{* *}$ & 24.12 & -5.76 & -8.57 & 4.76 & 0.00 \\
\hline TU-40 × PU-31 & $86.80^{* *}$ & $76.08^{* *}$ & $9.02^{*}$ & 3.10 & $-12.59^{* *}$ & $-15.71^{* *}$ \\
\hline TU-40 × IPU-2-43 & 18.05 & -2.80 & $9.19^{*}$ & 1.36 & -2.99 & -5.80 \\
\hline TU-40 × TBG-104 & $67.45^{* *}$ & $31.38^{* *}$ & $-10.25^{\star}$ & $-14.34^{* *}$ & 6.06 & 4.48 \\
\hline TU-40 × GBG-1 & $60.19^{* *}$ & $43.97^{\star *}$ & 5.39 & 4.26 & 0.80 & -3.08 \\
\hline PU-31 × IPU-2-43 & 2.22 & -11.54 & 3.55 & 1.52 & $-15.11^{\star *}$ & $-15.71^{* *}$ \\
\hline PU-31 × TBG-104 & 8.24 & -11.08 & -1.61 & -2.56 & -5.11 & -7.14 \\
\hline PU-31 × GBG-1 & $61.45^{* *}$ & $53.45^{\star *}$ & -3.21 & -7.52 & 3.08 & -4.29 \\
\hline IPU-2-43 × TBG-104 & $27.00^{* *}$ & $19.38^{*}$ & 8.01 & 4.90 & $-11.76^{\star \star}$ & $-13.04^{\star *}$ \\
\hline IPU-2-43 × GBG-1 & 12.74 & 2.10 & -1.80 & -7.92 & -0.78 & -7.25 \\
\hline TBG-104 × GBG-1 & 6.64 & -8.62 & -5.34 & -8.71 & -3.94 & $-8.96^{*}$ \\
\hline S.E. & 2.58 & 2.98 & 0.19 & 0.22 & 0.24 & 0.28 \\
\hline
\end{tabular}

*Significant at $5 \%$ level; ${ }^{*}$ Significant at $1 \%$ level.

$\mathrm{MH}-$ Mid parent heterosis; BH- Better parent heterosis. 
Studies on Heterotic Trends in Blackgram [Vigna mungo (L.) Hepper] for Yield and Earliness

Table 5: Percentage of mid parent heterosis $(\mathrm{MH})$ and better parent heterosis $(\mathrm{BH})$ for seed yield per plant $(\mathrm{g}), 100$ seed weight $(\mathrm{g})$ and harvest index (\%).

\begin{tabular}{|c|c|c|c|c|c|c|}
\hline \multirow{2}{*}{ Crosses } & \multicolumn{2}{|c|}{ Seed yield per plant $(\mathrm{g})$} & \multicolumn{2}{|c|}{100 seed weight $(\mathrm{g})$} & \multicolumn{2}{|c|}{ Harvest index (\%) } \\
\hline & $\mathrm{MH}$ & $\mathrm{BH}$ & $\mathrm{MH}$ & $\mathrm{BH}$ & $\mathrm{MH}$ & $\mathrm{BH}$ \\
\hline LBG-752 × TU-40 & $74.16^{* *}$ & $53.79^{* *}$ & -1.32 & -8.75 & $12.92^{*}$ & 6.03 \\
\hline LBG-752 × PU-31 & $65.70^{* *}$ & $44.42^{* *}$ & -0.24 & -4.33 & $21.31^{* *}$ & $19.29^{*}$ \\
\hline LBG-752 × IPU-2-43 & -4.93 & -9.92 & $9.94^{*}$ & 1.26 & -9.37 & $-15.41^{*}$ \\
\hline LBG-752 × TBG-104 & $80.81^{* *}$ & $66.27^{\star *}$ & 7.63 & 1.8 & $30.17^{* *}$ & $24.71^{* *}$ \\
\hline LBG-752 × GBG-1 & $31.79^{*}$ & 14.02 & -4.11 & -9.56 & -3.40 & -3.50 \\
\hline TU-40 × PU-31 & $58.20^{* *}$ & $55.84^{\star \star}$ & 2.45 & -1.38 & 0.61 & -7.00 \\
\hline TU-40 × IPU-2-43 & 20.02 & 1.15 & -2.88 & -3.29 & 6.12 & 5.44 \\
\hline TU-40 × TBG-104 & $40.59^{* *}$ & 15.49 & 2.54 & 0.10 & $14.19^{*}$ & 11.82 \\
\hline TU-40 × GBG-1 & $40.82^{* *}$ & $37.54^{*}$ & $13.04^{*}$ & 10.68 & $12.89^{*}$ & 5.91 \\
\hline PU-31 × IPU-2-43 & -21.41 & $-34.57^{* *}$ & -6.15 & -10.02 & 3.47 & -4.92 \\
\hline PU-31 × TBG-104 & 0.26 & -18.61 & -6.63 & -7.96 & $13.19^{*}$ & 6.71 \\
\hline PU-31 × GBG-1 & $65.63^{* *}$ & $64.20^{* *}$ & 2.25 & 0.49 & $13.4-$ & 11.63 \\
\hline IPU-2-43 × TBG-104 & 7.50 & 4.14 & $10.97^{*}$ & 7.89 & -4.38 & -6.96 \\
\hline IPU-2-43 × GBG-1 & 8.40 & -10.37 & 0.57 & -1.93 & 0.26 & -6.51 \\
\hline TBG-104 × GBG-1 & 15.82 & -6.6 & 5.17 & 4.85 & $13.80^{*}$ & 8.92 \\
\hline S.E. & 0.69 & 0.79 & 0.23 & 0.27 & 2.26 & 2.61 \\
\hline
\end{tabular}

${ }^{*}$ Significant at $5 \%$ level; ${ }^{*}$ Significant at $1 \%$ level.

$\mathrm{MH}-$ Mid parent heterosis; $\mathrm{BH}-$ Better parent heterosis.

In the present investigation, expression of high heterosis for seed yield was manifested through high heterosis for other yield attributing traits like clusters per plant, pods per cluster and pods per plant etc. The degree of heterosis varied from cross to cross for all the traits. Considerable heterosis in certain crosses and lower estimates in others revealed that nature of gene action varied with the genetic make-up of the parents.

High non-additive genetic variation was found to be evident for most of the yield attributing traits as indicated by heterosis. Although it confers no major advantage in an autogamous crop like blackgram at present, such genetic variation would be a highly valuable tool as and when a workable and economic male sterility system is identified (Sagar and Chandra, 1977). However, commercial exploitation of heterosis in the form of hybrid varieties is not possible in case of blackgram as it is highly self-pollinated crop. Nonetheless, the crosses showing higher heterotic effects may be advanced to isolate purelines which are better than parents utilizing the principle of transgressive segregation.

\section{CONCLUSION}

This study highlights the existence of varying degrees of heterosis in desirable direction among crosses for various traits, which could be exploited for the development of short duration, high yielding blackgram varieties. The combinations viz., LBG-752 × TBG-104, LBG-752 × PU-31, TU-40 $\times$ TBG-104, LBG-752 $\times$ TU-40 and IPU-2-43 x TBG104 were the best crosses that can be included in breeding programs aimed at developing early maturing and high yielding blackgram varieties.

\section{ACKNOWLEDGEMENT}

A. Kavitha Reddy is thankful to DST Inspire (Department of Science and Technology, Ministry of Science and Technology, Government of India) for aiding financial assistance under Inspire fellowship program during the course of study and S.V. Agricultural College, Tirupati, ANGRAU for providing resources for carrying out doctoral research work.

\section{REFERENCES}

Ahlawat, I.P.S., Sharma, P. and Singh, U. (2016). Production, demand and import of pulses in India. Indian Journal of Agronomy. 61: 33-41.

Bhagirath, R., Tikka, S.B.S. and Acharya, S. (2013). Heterosis and combining ability in blackgram (Vigna mungo) under different environments. Indian Journal of Agricultural Sciences. 83: 611-616.

Elangaimannan, R., Anbuselvam, Y., Venkatesan, M. and Karthikeyan, P. (2008). Heterosis and inbreeding depression for yield and yield attributes in urdbean. Madras Agricultural Journal. 95: 453-457.

Elangaimannan, R., Karthikeyan, P., Venkatesan, M. and Saravanan, K.R. (2018). Heterosis breeding in blackgram [Vigna mungo (L.) Hepper]. Plant Archives. 18: 335-338.

Fonesca, S. and Patterson, F.L. (1968). Hybrid vigour in seven parent diallel cross in common winter wheat (Triticum aestivum L). Crop Science. 8: 85-88.

Kalia, R.K., Gupta, V.P. and Kalia, N.R. (1988). Estimates of heterosis and inbreeding for seed yield over locations in urdbean. Indian Journal of Pulses Research. 1: 43-49.

Kant, R. and Srivastava, R.K. (2012). Heterosis and inbreeding depression studies in urdbean [Vigna mungo (L.) Hepper]. Journal of Food Legumes. 25: 102-108. 
Karande, S.P., Rewale, A.P. and Nilakh, S.B. (2013). Heterosis for yield and yield attributing traits in black gram [Vigna mungo (L.) Hepper]. Bioinfolet. 10: 679-684.

Kumar, V.G., Vanaja, M., Babu Abraham, Premkumar, Jyothi Lakshmi, N. and Sarkar, B. (2017). Heterosis and combining ability studies in blackgram [Vigna mungo (L.) Hepper] under alfisols of SAT region, India. Electronic Journal of Plant Breeding. 8: 541-547.

Neog, S.B. and Talukdar, P. (1999). Combining ability and heterosis in blackgram. Journal of the Agricultural Science Society of North-East India. 12: 210-216.

Paschal, E.H. and Wilcox, J.R. (1975). Heterosis and combining ability in exotic soybean germplasm. Crop Science. 15(3): 344-349.

Sagar, P. and Chandra, S. (1977). Heterosis and combining ability in urdbean. Indian Journal of Genetics and Plant Breeding. 37: 420-424.

Saravanan, K., Sabesan, T., Thangavel, P., Kumar, J.S. and Ganesan, J. (2004). Heterosis for yield and yield components in black gram [Vigna mungo (L.) Hepper]. Legume Research. 27: 209-212.
Shalini, C.H. and Lal, G.M. (2019). Heterosis and combining ability studies for yield and yield components in blackgram [Vigna mungo (L.) Hepper] under different environmental conditions of Prayagraj region, India. Journal of Pharmacognosy and Phytochemistry. 8: 3512-3516.

Shull, G.H. (1908). What is "Heterosis"? Genetics. 33: 439-446.

Snedecor, G.W. and Cochran, W.G. (1967). Statistical Methods. $6^{\text {th }}$ Edition. lowa State University Press. Ames, lowa.

Suguna, R., Savitha, P. and Ananda Kumar, C.R. (2017). Inheritance of genetic variability, combining ability and heterosis for yellow mosaic virus disease resistance and yield improvement in Blackgram [Vigna mungo (L.) Hepper]. International Journal of Current Microbiology and Applied Sciences. 6: 2416-2442.

Thamodharan, G., Geetha, S., Ramalingam, A. and Ushakumari, R. (2016). Studies on heterosis in blackgram [Vigna mungo (L.) Hepper]. Electronic Journal of Plant Breeding. 7: 670-676. 